about these things is saddening. It betrays a pathetic lack of scientific faith ${ }^{1}$.

Yours faithfully,

V. B. WIGGLESWORTH

Gonville and Caius College, Cambridge

1 Wigglesworth, V. B., Ann. Appl. Biol., 60, 1 (1967).

\section{Noah's Haemoglobin}

SIR, - In the ecumenical interest (Nature, 239, 420; 1972), we wish to point out that the latter portion of Genesis is consistent with current theory of molecular evolution.

Kimura (Nature, 217, 624; 1968) and King and Jukes (Science, 164, 788; 1969) propose that protein evolution has occurred mainly through neutral mutations which have no effect on molecular function and no selective advantage. Haigh and Maynard Smith (Genet. Res., 19, 73; 1972) have examined this theory with respect to the published data on human haemoglobin variation. They conclude that if the theory is correct the human population must have passed through a period of drastically reduced size prior to the more recent rapid population increase. The population bottleneck is necessary to give initial genetic homogeneity, a requirement for agreement of theory and observation.

Genesis, chapter 6, contains a full description of events causing a reduction in the human population to eight individuals; Noah, his wife, their three sons, Shem, Ham and Japheth, and the sons' wives. It seems entirely plausible that this small population could be homogeneous for haemoglobin genes. Thus the book of Genesis documents a series of human population changes which are consistent with changes required from consideration of amino-acid sequences alone.

Yours faithfully, RICHARD N. HARKINS Peter STEnzel JOHN A. BLACK

Department of Biochemistry and Division of Medical Genetics, University of Oregon Medical School, Portland, Oregon 97201

\section{Titles and Reprints}

SiR,-As a librarian, I can easily answer the puzzle postulated by Briggs and Briggs $^{1}$ as to why more requests were received for a paper published in Contraception $^{2}$ than for the one in
Nature ${ }^{3}$. Nature is more readily available. Virtually all scientific libraries have at least one subscription to Nature; whereas relatively few subscribe to the highly specialized Contraception.

Even though photocopying is cheaper than mailing a request, without the journal at hand a reprint is necessary.

Also as a librarian, I want to admonish the editor of Nature for publishing a paper with a deliberately misleading title. This paper will turn up as a false drop for years to come. The use of titles has become a powerful literature searching technique ${ }^{4}$. It is bad enough that uninformative titles are still being written through ignorance, but to write phoney titles intentionally is just outright perverse.

$$
\text { Yours faithfully, }
$$
DONALD A. WINDSOR

Biological Research Department,

SciAesthetics Institute,

Post Office Box 604,

Norwich, New York 13815

1 Briggs, M. H., and Briggs, M., Nature, 240, 490 (1972).

2 Briggs, M. H., Briggs, M., and Austin, J., Nature, 232, 480 (1971).

${ }^{3}$ Briggs, M. H., and Briggs, M., Contraception, 3, 381 (1971).

4 Windsor, D. A., J. Chem. Document., 11, 227 (1971).

\section{Announcements}

\section{University News}

Dr William Robert Dearman, Newcastle upon Tyne, has been appointed to a professorship in engineering geology from August 1, 1972.

Dr Alan Williams, Leeds University, has been appointed Livesey professor and head of the Department of Fuel and Combustion Science from January 1, 1973.

Dr G. C. Morrison, Illinois, USA, has been appointed to the Chair of Nuclear Structure at the University of Birmingham.

Professor Roger Penrose, Birkbeck College, London, has been appointed to the Rouse Ball Professorship of Mathematics, at the University of Oxford, in succession to Professor C. A. Coulson, Oxford.

\section{Appointments}

Dr Edwin Clarke, MD, FRCP, has been appointed Director of the Wellcome Institute of the History of Medicine as from October 1, 1973.

\section{Miscellaneous}

The Lomonsov Gold Medals for 1972the highest award of the Soviet Academy of Sciences, awarded annually for out- standing achievements in the natural sciences to one Soviet and one foreign scientist-have been awarded to Academician Nikolsi Ivanovich Muskhelishvili for his work in mathematics and mechanics, and to Professor Max Steenbeck (German Democratic Republic) for his research on plasma physics.

Professor Arpad I. Csapo, Washington University, has been awarded the 1972 award of the International Health Foundation on "Prospects for Practical Application of Prostaglandins".

\section{International Meetings}

The University of Texas Health Science Center, Houston, announces the Tenth Symposium on Biomathematics and Computer Science in the Life Sciences to be presented at Houston, Texas, March 1973. (Dr Stuart Zimmerman, University of Texas.)

\section{Reports and Publicutions}

not included in the Monthly Books Supplement

\section{Great Britain and Ireland}

Agricultural Research Institute of Northern Ireland. Forty-fifth Annual Report, 1971/1972. Pp. 43. (Hillsborough, Co. Down: Agricultural Research Institute of Northern Ireland, 1972.) Shipping. (2910 Towards a Future for Inland Shipping. (Comments by the Inland Waterways Association on the
Future of Inland Waterways Transport in the Light of the Proposed Regional Water Authorities.) Pp. 12. (London: The Inland Waterways Association, 1972.) 20p.

Bulletin of the British Museum (Natural History) Entomology. Vol. 27, No. S: On Eurropen Pleonyms. Eunotus and Spaniopus, with Descriptions of New
Genera and Species. By Z. Boucek. Pp. 265-315. $£ 1.85$. Historical Series. Vol. 4, No. 3: Charles Darwin's Queries About Expression. By Richard Broke Frecman and Peter Jack Gautrey Pp. 205$219+1$ plate. $65 \mathrm{p}$. Zoology. Vol. 23, No. 1: The Gunong Bennm Expedition 1967. 1: Introduction. By Lord Medway. Pp. 1-7+4 plates. 75p. Vol. 23.
No. 2: The Gunong Benom Expedition 1967. 2: An Outline Description of the Forest Zones on North-East Gunong Benom. By T. C. Whitmore. 3: Bryophytes and Filmy Ferns from Gunong Benom. By Anne Johnson. Pp. $9-20+8$ plates. £1.15. Vol. 23, No. 4: The Gunong Benom Expedition 1967. a Description of a New Species of Macrocalamus. By a Description of a New Species of Macrocalamus. By No. 7: The Gunong Benom Expedition 1967. 8: Ticks (Ixodidae) of Gunong Benom and Their Altitudinal Distribution, Hosts and Medical Relationships. By H. Hoogstraal, B. L, Lim, M. Nadchatram and The Gunong Benom Expedition 1967. 9: A Collec tion of Chiggers from Gunong Benom (Prostigmata: Trombiculidae). By M. Nadchatram. 10: Phthiraptera (Insecta) Chewing and Sucking Lice. By Theresa Clay. Pp. 187-200. 65p. (London: British Museum (Natural History), 1972.)
Philosophical Transactions of the Royal Society of London. A: Mathematical and Physical Sciences. Vol. 273, No. 1233: Dynamics of the Liquid Core of the Eanth. By C. L. Pekeris and Y. Accad. Pp $237-260$. (London: The Royal Society, 1972.) 65p:
[2910 \$1,80, Handbook 1973. PD. $294+75$ photographs.
BBC Haphe BBC Handbook 1973. PD. 294+75 photographs.
[3110 Imperial College. Royal School of Mines Research Imperial College. Royal School of Mines Research Report 199-72. Geology, Mining and Mineral Tech nology, Metallurgy.) Pp. 64. (London: Imperia Procter Procter and Gamble timited. Annual Report Newcastle upon Tyne: Procter and Gamble, Ltd. 1972.) $[3110$ Post Office Investment for the Future. Pp. 24 London: Post Once, 1972.) Special Report No Geological Society of London. Special Report No. 2: A Correlation of Cambrian Rocks in the British Isles. By John Watson Cowie, Adrian 42. £1.20; \$3. Special Report No. 3: A Correlation of Ordovician Rocks in the British Isles. By A. Williams, I. Strachan, D. A. Bassett, W. T. Dean, J. K. Ingham, A. D. Wright and H, B. Whittington. Pp. 74, £1,20; \$3. (Edinburgh: Scottish Academic Press, Ltd., 1972.) [311 Forestry Commission. Rescarch and Development Papers. No. 87: Production and Use of Ballrooted Planting Stock in Sweden and Finland. By A. J. Low and R. M. Brown P. 25. No. 88: tion in the Field. By O. N. Blatchord. Pp. 4. No. 89: Formulation and Implementation of Forest 